\title{
Os EUA e a revisão periódica universal do Conselho de Direitos Humanos da ONU
}

\section{The United States and the universal periodic review of the UN Human Rights Council}

DOI: 10.5752/P.2317-773X.2017v6.n1.p127

Matheus de Carvalho Hernandez ${ }^{1}$

William Torres Laureano da Rosa²

\section{RESUMO}

A Revisão Periódica Universal é a maior novidade institucional em matéria de monitoramento de direitos humanos criada pela ONU juntamente com o surgimento do Conselho, em 2006. Por meio desse mecanismo, todos os Estados membros da ONU passam a ter suas práticas e políticas de direitos humanos analisadas por seus pares ao longo de um ciclo de quatro anos. Os Estados Unidos sempre mantiveram uma relação tensa com o Conselho de Direitos Humanos, especialmente durante o governo Bush, que boicotou financeiramente o órgão, e agora atualmente durante o governo Trump. Entretanto, ainda há pouca literatura a respeito dos dois ciclos de revisão pelos quais os EUA passaram, ambas no governo Obama. Assim, além da análise histórica que culminou na entrada dos EUA no órgão após o fim do governo Bush, este artigo traz consigo um esforço inédito de mapeamento comparativo desses dois ciclos, sistematizando de quais países são oriundas as recomendações direcionadas aos EUA, quais são as temáticas prioritariamente abordadas e quais são as posturas dos EUA diante dessas recomendações. O objetivo é compreender o funcionamento desse mecanismo inédito e, principalmente, a atuação dos EUA, de modo a contribuir com a abertura dessa agenda de pesquisa.

Palavras-chave: Conselho de Direitos Humanos; Revisão Periódica Universal; Estados Unidos.

\section{ABstract}

The Universal Periodic Review is the newest institutional mechanism of monitoring human rights created by the UN together with the emergence of the Council in 2006. Through this mechanism, all UN member states have begun to have their human rights practices and policies analysed by their peers over a four-year cycle. The United States has always had a tense relationship with the Human Rights Council, especially during the Bush administration, which boycotted it financially, and currently under Trump. However, there is still little literature on the two review cycles the US passed, both under the Obama administration. In addition to the historical analysis that culminated in the US entry into the body after the end of the Bush administration, this article brings with it an unprecedented effort of comparative mapping of these two cycles. It systematizes from which countries the recommendations directed to the US come from, what are the issues and what are the US positions on these recommendations. The objective is to understand how this unprecedented mechanism operates and, mainly, the performance of the USA, in order to contribute to the opening of this research agenda.

Keywords: Human Rights Council; Universal Periodic Review; United States of America. 
Introdução

Os Estados Unidos da América (EUA) nutrem historicamente uma tensa relação com o chamado regime internacional de direitos humanos, majoritariamente assentado no sistema da Organização das Nações Unidas (ONU). A tensão se dá porque os EUA são um dos grandes promotores desse regime, por um lado, participando ativamente de várias negociações, mas, de outro lado, muitas vezes não aderem às instituições que compõem essa arquitetura institucional e aos acordos multilaterais que dela afloram.

O caso da relação dos EUA com o Conselho de Direitos Humanos $(\mathrm{CDH})$ da ONU é muito interessante. O Conselho foi precedido pela Comissão de Direitos Humanos, criada na fundação da ONU. Os EUA historicamente foram um país importante da Comissão, apesar das muitas críticas que sempre fizeram em relação a ela. Nos anos 2000, em meio ao impulso reformista desencadeado por Kofi Annan, então Secretário-Geral da ONU, os EUA, sob a administração Bush, foi um dos principais países a advogar a supressão da Comissão por um Conselho restaurado.

Número de membros, frequência de reuniões, critérios para eleição de membros, politização das discussões sobre direitos humanos, entre outros pontos, constituíam as principais críticas à então Comissão. Com o transcorrer das negociações, os EUA, naquele momento muito criticados pelas formas de combate ao terrorismo e, especialmente, pela invasão ao Iraque à revelia da $\mathrm{ONU}$, não tiveram muitas de suas demandas atendidas.

Diante disso, foi, juntamente com os Israel e mais apenas outros dois países, as únicas delegações a votarem contrariamente à criação do novo Conselho de Direitos Humanos da ONU em 2006. Dessa forma, tornou-se apenas membro observador. E como tal, teceu frequentes e fortes críticas ao novo órgão justamente em razão daqueles pontos acima citados e, especialmente, pela ênfase, demasiada segundo os EUA, que o Conselho dispensava à Israel. Essa tensão chegou ao seu auge em 2008, quando o governo Bush passou a boicotar política e financeiramente o novo órgão.

Os EUA só voltaram ao Conselho em março de 2009, quando o governo Obama se candidatou a uma cadeira e foi, posteriormente, eleito. Assim, o Estado mais poderoso do sistema internacional passou a integrar aquele fórum e se viu, tal como todos os outros Estados, engajado na principal inovação institucional trazida em relação à extinta Comissão: o mecanismo de Revisão Periódica Universal (RPU). Esse mecanismo prevê que todos os países da ONU passem por uma revisão da sua situação de direitos humanos a cada quatro anos e meio. O Estado sob revisão recebe recomendações dos outros Estados e, diante delas, precisa se posicionar individualmente em relação a cada uma delas, aceitando-as ou não. Portanto, esse é um mecanismo que visa remediar a tradicional acusação de politização ao sistema de direitos humanos trazendo a ele, do ponto de vista institucional, um dispositivo pelo qual todos os países indiscriminadamente passam.

Como parte do universo apresentado, este artigo é um esforço de cunho exploratório, tendo em vista a escassez de literatura sobre o tema, 
que pretende analisar a trajetória dos EUA em relação ao Conselho a partir da atitude de negação e enfrentamento pelo governo Bush, passando pela entrada do país com o assento conquistado pelo governo Obama e culminando com as duas revisões pelas quais os EUA passaram ao longo do governo democrata em 2010 e 2015. Neste esforço, o Conselho de Direitos Humanos torna-se tanto um espaço de disputa pela definição dos direitos humanos e a forma de aplicação, quanto um "espaço" que define esses direitos (RUGGIE, KRATOCHWIL, 1986; HASENCLEVER, MAYER, RITTBERG, 1997). Neste sentido, a participação dos EUA no mecanismo é importante por compreender que há um interesse da grande potência em atuar/controlar os termos dessa definição. Isso porque a atuação da potência hegemônica a partir do controle e expansão da sua visão dos direitos humanos não é estranho ao campo (MIGNOLO, 2000). Dessa forma, além da análise histórica que culminou na entrada dos EUA no órgão, este trabalho apresenta um esforço inédito de mapeamento dos dois ciclos de Revisão Periódica Universal pelos quais o país passou. O objetivo é sistematizar, de forma comparada entre os dois ciclos, de quais países advêm as recomendações feitas aos EUA, quais são os temas prioritários e quais são as posturas dos EUA em relação à aceitação ou não das recomendações. Espera-se que a compreensão do mecanismo enquanto tal e da atuação dos EUA enquanto país em revisão e país revisor possa contribuir com a abertura dessa agenda de pesquisa.

A política externa dos EUA para direitos humanos e a politização do Conselho de Direitos Humanos

Algumas análises da política externa dos EUA para direitos humanos apresentam pelo menos quatro modelos explicativos. O primeiro modelo é o chamado Cosmopolitismo iluminista, de cunho eminentemente wilsoniano e que é manifestado em ONGs com a Human Rights Watch e a American Civil Liberty Union. O segundo é o dito nacionalismo paroquial, que prega a ideia do destino manifesto, na qual existem um excepcionalismo patente nas determinantes históricas, sociológicas, políticas e econômicas no plano doméstico do Estado que faz com que ele se torne "um farol na montanha", a "luz do mundo". O terceiro modelo é o do realismo político e, por fim, o quarto modelo é o do pragmatismo casuístico. Neste caso, a política externa para direitos humanos seria menos guiada por questões ideológicas ou identitárias partidárias, e mais por uma atuação que se movimentaria de acordo com as necessidades do caso concreto. Isso porque unidade e interesse nacionais tendem a estar acima da agenda de direitos humanos (FORSYTHE, 2011).

Assim, quanto mais de perto se examina a condução da política externa em direitos humanos, se atentando aos diferentes casos, mais exceções e misturas se identificam. Segundo Forsythe (2011), as administrações, especialmente no segundo mandato, tendem a caminhar para o pragmatismo casuístico em virtude de três elementos: da força do autointeresse em um sistema internacional competitivo (válido especialmente no campo da segurança e da economia); da transversalidade quantitativa e qualitativa da agenda ampliada da política externa ao longo de quase 
3. This is not to say that some states cannot compile a relatively more liberal record in foreign policy than others. But it is to say that any one state's record over time will be mixed or inconsistent, as is true of the US record in the Western Hemisphere. And it is to say that anyone expecting, for example US consistent observance of the international law of human rights will be profoundly disappointed.
200 países e muitas organizações internacionais diante de uma longa lista de direitos humanos internacionalmente reconhecidos; e da força cambiante das pressões domésticas e externas. A regra, portanto, da condução da política externa em direitos humanos não é o padrão, nem mesmo a continuidade das ideias defendidas pelo executivo no início do mandato (realista, liberal, neo-conservadora). Se há um padrão, é o de que a administração tende a se render ao pragmatismo casuístico. Esse movimento em direção ao pragmatismo casuístico também ocorreu no segundo mandato da administração Obama, por exemplo. Diz Forsythe:

Isso não quer dizer que alguns estados não possam compilar um registro relativamente mais liberal em política externa do que outros. Mas é para dizer que o registro de qualquer estado ao longo do tempo será misto ou inconsistente, como é o caso do registro americano no Hemisfério Ocidental. E é para dizer que qualquer um que espere, por exemplo, a observância consistente dos EUA da lei internacional dos direitos humanos será profundamente desapontado ${ }^{3}$ (FORSYTHE, 2011, p. 773, tradução nossa).

Nesse sentido, por exemplo, contrariando a Convenção contra a Tortura (da qual os EUA são signatários) e as Convenções de Genebra, Obama foi contra processar os funcionários da era Bush responsáveis por práticas de tortura após o 11/09 com o argumento de que isso dividiria o país e atrapalharia a aprovação de reformas, como a reforma da saúde, cuja aprovação dependia de uma aliança com os republicanos.

A postura excepcionalista é interessante porque pode fomentar tanto um isolacionismo dos EUA (como aquela que fez vista grossa para as atrocidades iniciais cometidas por Hitler) quanto, uma vez engajado internacionalmente, gerar a expectativa de que os EUA deixarão uma marca de democracia e liberdades por onde passam (o que gerou, por exemplo, os desastres do Iraque e Afeganistão). Neste caso, a Constituição dos EUA passa a ter um papel unificador simbólico muito grande e acaba se confundindo com os próprios valores americanos que devem ser, necessariamente (segundo essa visão), exportados para o mundo. Segundo essa visão, a Constituição é suprema e nada e nem nenhuma outra lei podem diminuir o seu status, nem mesmo qualquer tratado internacional. Consequentemente, a aceitação de tratados ou de jurisdições internacionais por outras soberanias jurídicas tentem a ser entendidas como um elemento de inferioridade.

A administração Bush esteve mais firme na perspectiva do excepcionalismo americano em relação à política externa. Neste ponto, em seu primeiro mandato, procurou acabar com o Tribunal Penal Internacional (TPI) e impediu a renovação do mandato de Mary Robinson como Alta Comissária das Nações Unidas para os Direitos Humanos. Isso porque ela já havia criticado publicamente as posições estadunidenses nos casos de Guantánamo e no tratamento dado pelos governos de Israel aos palestinos. Além disso, a administração Bush procurou expandir o seu nacionalismo providencial ao glorificar e apoiar as ditas virtudes norte-americanas mesmo que contra a posição de críticas internacionais (FORSYTHE, 2011, p. 776-778).

As posturas das administrações, entretanto, não permanecem sempre no mesmo polo. Todos os presidentes dos EUA precisam expressar publicamente que seus mandatos serão fiéis aos direitos humanos inter- 
nacionalmente reconhecidos e todos são pressionados a fazer. Entretanto, uma vez declarado o apoio aos direitos humanos, as administrações passam para um segundo momento no qual precisam justificar o apoio dos EUA a aliados não liberais e às suas políticas. Nesse sentido, acabam caindo no pragmatismo casuístico a partir do qual por vezes atuam conforme as normas internacionais de direitos humanos e às vezes, não. Obama, por exemplo, manteve várias políticas de Bush no combate ao terrorismo: ele afirmou que os EUA estavam em guerra contra a Al Qaeda; ele se valeu de prerrogativas presidenciais para detenções em vez de elaborar ou buscar uma estrutura estatutária; ele continuou a usar as comissões militares para julgar prisioneiros e a detenção administrativa sem acusação legal ou julgamento; ele seguiu enviando detidos para outros Estados via rendição "extraordinária" (supostamente com melhores garantias diplomáticas em relação a tratamentos desumanos); e sua equipe jurídica, tal como a de Bush, usou o argumento de "segredos de Estado" para tentar manter o judiciários de fora de um grande número de casos.

O mesmo tipo de pragmatismo casuístico observado na política externa de direitos humanos de Obama como um todo também pode ser visto nas políticas de direitos humanos na ONU. Obama decidiu de forma exitosa colocar a candidatura dos EUA ao recém-criado Conselho, revertendo a política de boicote de Bush, como veremos mais abaixo. Mas quando o Conselho solicitou à Comissão Goldstone que investigasse acusações de crimes contra a humanidade cometidos por Israel e pelo Hamas durante o conflito em Gaza, a administração Obama se colocou prontamente ao lado de Israel na empreitada de desqualificar esse relatório. O Congresso, por sua vez, publicou uma nota bipartidária tecendo fortes críticas, a despeito do fato de ele ter indicado várias violações cometidas também pelo Hamas ${ }^{4}$ (FORSYTHE; PARK, 2009).

Em relação ao TPI, Obama, diferentemente de Bush (que chegou, no máximo, a tolerar o tribunal a fim de lidar com o Sudão), indicou representantes para observar as reuniões, mas não mais que isso. Ele não recuperou a assinatura do Tratado de Roma, do qual Bush retirou a assinatura (Clinton havia assinado a fim de dar oportunidade aos EUA de especificamente participar no estabelecimento das regras e regulamentos da Corte). Obama tampouco submeteu o tratado ao Senado, prevendo a controvérsia que seria gerada entre os senadores.

Apesar de algumas diferenças em relação a Bush, como a preocupação com civis em zonas de guerra no Afeganistão, a grande diferença entre a administração Obama e sua antecessora foi seu discurso, carregado de tons multilaterais e multiculturais, contrastando muito com o nacionalismo paroquialista de Bush e John Bolton, seu representante na ONU. Mas, segundo Forsythe, afora a retórica, as políticas de Obama não foram radicalmente diferentes da maioria das outras administrações. Autointeresse calcado em segurança e economia foram priorizados, atendendo às audiências domésticas, gerando o reincidente desapontamento nas chamadas elites liberais cosmopolitas.

Obama representou uma mudança incompleta em relação a Bush quanto à política externa de direitos humanos. Forsy the (2011), entretanto, afirma que nenhuma presidência dos EUA irá implementar plenamente a
4. Enquanto a maioria dos apoiadores de Israel atacaram o Relatório Goldstone, acusando-o de viés em desfavor do Estado judeu, a Anistia Internacional afirmou que o Relatório coincidia com as suas próprias investigações a respeito da ocorrência de crimes de guerra no Oriente Médio. Ver mais em: “UN Must Ensure Goldstone Inquiry Recommendations Are Implemented" 15 Set. 2009, disponível em: http://www.amnesty. org/en/newsand-updates/news/israel-gaza-implementation-un-fact-finding-mission-recommendations-crucialjusti. $0 \mathrm{CDH}$, com seu número significativo de membros africanos, árabes e asiáticos, enfatizava demasiadamente, segundo Forsythe (2009), as críticas a Israel, tal como ocorria na extinta Comissão de Direitos Humanos. Nesse sentido especificamente, a presença dos EUA dentro do Conselho fez pouca diferença, pois a Organização da Conferência Islâmica e a Liga dos Estados Árabes trabalharam incessantemente para manter um foco constante sobre Israel. Por outro lado, o suporte dos EUA foi importante para que Israel conseguisse que o follow-up do relatório se ativesse apenas a alguns indivíduos do baixo escalão em vez de abordar a questão como uma política de uso desproporcional da força conduzindo a possíveis crimes de guerra cometidos por Israel. 
5. 0 Like Minded Group (LMG) é um grupo de países em desenvolvimento que se organizam em coalizão para negociar em várias instâncias da ONU e da OMC Apesar de uma configuração fluida, seus principais membros são Argélia, Bangladesh, Belarus, Butão, China, Cuba Egito, Índia, Indonésia, Irã, Malásia Myanmar, Nepal, Paquistão, Sri Lanka, Sudão, Síria, Vietnam e Zimbábue. agenda liberal de direitos humanos, pois todo presidente precisa responder a fortes pressões domésticas por vantagens econômicas e segurança nacional, afora outros interesses poderosos. Apesar disso, ainda segundo o autor, perseguir ganhos econômicos não precisa necessariamente implicar em políticas de redução de direitos trabalhistas ou a persecução da segurança nacional não tem que necessariamente culminar em tortura e abusos de inimigos. Portanto, haveria ainda espaço para avançar pragmaticamente, pois, na visão de Forsythe, progresso incremental e parcial ainda é progresso, desde que ele ocorra.

Assim, ao observarmos a política externa dos EUA para os direitos humanos e o seu engajamento na Revisão Periódica Universal, veremos o grau de politização desse organismo. Ainda que a reforma do sistema de direitos humanos no início da primeira década dos anos 2000 tenha gerado fortes debates, ela tinha alguns consensos: de que a Comissão de Direitos Humanos havia falhado, de que era necessária uma nova organização com um status maior e de que a maquinaria institucional da ONU no campo dos direitos humanos precisava ser fortalecida. Entretanto, pouco acordo existiu sobre os motivos que levaram ao fracasso da Comissão.

Na tentativa de explorar os problemas que levaram a essa situação e à criação da RPU, Philip Alston discorre sobre as críticas de países desenvolvidos e ONGs de um lado e do "Like Minded Group" e de outros países em desenvolvimento do outro. Enquanto o primeiro grupo criticava a falta de condenação de países claramente violadores de direitos humanos em razão de relações e alianças políticas em outros campos, o outro grupo, capitaneado pela China, pedia o fim de críticas a Estados específicos e queria um conjunto de procedimentos que fossem mais gerais e cooperativos. O "Like Minded Group" atuou entre 1997 e 2006 na tentativa de reforma do mecanismo, apresentando sucesso relativo em relação às medidas propostas por eles (ALSTON, 2006, p. 20-21).

No ano de 2005, o descontentamento com os procedimentos e a substância dos resultados da Comissão fez com que parte desse grupo vocalizasse suas manifestações de forma mais efetiva na abertura dos trabalhos daquele ano. Assim, os representantes da Indonésia e do Egito pediram que as delegações deixassem de usar declarações e referência difamatórias com relação às violações de direitos humanos pelos Estados, enquanto que Coreia do Sul, Paquistão, China e Cuba alertaram para o alto grau de politização do organismo. Criticaram a fórmula de resoluções específica para países, desenvolvida em meio a um ambiente altamente politizado e manipulador, onde operaria um sistema de padrões-duplos e que, assim, estaria perdendo objetividade, credibilidade e imparcialidade e gerando mais conflitos e menos diálogo (ALSTON, 2006, p. 21-22). Portanto, os dois principais polos do debate acusavam, por diferentes motivos, a Comissão pela chamada politização dos debates sobre direitos humanos. Nesse sentido, o Conselho e a própria RPU são, assim, o resultado do embate entre os interesses ocidentais, que objetivavam um mecanismo que gerasse um procedimento crítico específico para países, e o "Like Minded Group", que desejava um processo mais geral e sem um fim determinado em matéria de constrangimentos a países específicos. 
O próprio Kofi Annan, em discurso dirigido a Comissão de Direitos Humanos em Genebra, em 7 de abril de 2005, alertou para a reforma do organismo apontando a politização como um problema a ser superado, ainda que sem propor uma solução:

[...]a capacidade da Comissão para desempenhar as suas tarefas foi ultrapassada
por novas necessidades e prejudicada pela politização das suas sessões e pela
seletividade do seu trabalho. Chegamos a um ponto em que a credibilidade em
declínio da Comissão fez sombra à reputação do sistema das Nações Unidas
no seu todo, e onde reformas fragmentadas não serão suficientes ${ }^{6}$ (ANNAN,
2005 ,tradução nossa).

Entende-se, assim, que a questão da politização da Comissão foi relevante para a construção do mecanismo atual. Dessa forma, existem leituras que tratam da politização dos organismos internacionais de direitos humanos como "a busca da agenda nacional de um Estado ou de objetivos comuns de um grupo regional, tomados de forma seletiva, parcial ou tendenciosa" (FREEDMAN, 2011, p. 289), ou ainda, a politização dessas organizações pode ser compreendida pela "tentativa de Estados de desenvolverem suas próprias agendas políticas introduzindo questões controvertidas" (LYONS; BALDWIN; MCNEMAR, 1977, p. 89, apud FREEDMAN, 2011, p. 290). A antiga Comissão de Direitos Humanos, assim, teria sido palco dessa politização que, no fim, impediu o seu funcionamento pleno. A Revisão Periódica Universal juntamente com as Sessões Especiais do Conselho são os mecanismos criados pelo Conselho de Direitos Humanos que pretendiam superar essa politização, a fim de que o organismo pudesse cumprir com o seu mandato.

Não há, entretanto, definição clara de como superar a dita politização. "Assim, também a politização dominou o processo de criação do mecanismo e fez com que houvesse apenas o mínimo de decisões técnicas, contra vasta influência de considerações políticas” (ABEBE, 2009, p. 3). A RPU, portanto, não resolve essa questão. O que é percebido no decorrer das sessões, é que há uma diferença muito grande entre os países ocidentais, que se utilizam dos espaços de discussão para fazer recomendações, contra Estados menores que tendem a não debater questões fora da sua região. Sugere-se que esses Estados temem desagradar a Estados mais poderosos. Além disso, a politização também se observa no momento em que os representados de um determinado Estado optam por blindar um aliado político na RPU e nos debates do CDH (FREEDMAN, 2011, p. 307-308). Ainda assim, a literatura é incapaz de mostrar uma solução para a politização. É incapaz, entretanto, não porque falte a ela criatividade ou inventividade, mas porque a politização de debates e fóruns internacionais sobre direitos humanos é simplesmente inescapável. À medida que os direitos humanos se tornam uma pauta da agenda global, eles se tornam um assunto eminentemente político, isto é, recortado pelas disputas e acordos políticos e isso está contido tanto nos avanços quanto nos problemas dos sistemas de direitos humanos.

Em suma, a politização foi um dos principais motes da reforma da Comissão e criação do Conselho. Além disso, os EUA de Bush foram uma das principais vozes a defender a necessidade da reforma em virtude dessa politização. A RPU talvez tenha sido a expressão maior dessa tentativa de descolar os debates internacionais sobre direitos humanos das ques-
6. The Commission's ability to perform its tasks has been overtaken by new needs, and undermined by the politicization of its sessions and the selectivity of its work. We have reached a point at which the Commission's declining credibility has cast a shadow on the reputation of the United Nations system as a whole, and where piecemeal reforms will not be enough 
7. Três abstenções: Belarus, Irã e Venezuela.

8. 0 embaixador John Bolton, que foi Representante Permanente para as Nações Unidas de $1^{\circ}$ de agosto de 2005 a dezembro de 2006, é um grande crítico

da ONU. É de sua autoria a famosa declaração de que se o prédio da ONU de 38 andares localizado em Manhattan perdesse dez (aqueles responsáveis pelas temáticas de direitos humanos), não faria a menor diferença. Portanto entendemos que a própria indicação de Bolton para representante na ONU dificultou um papel construtivo dos Estados Unidos na organização. Além disso,

Bolton é uma figura polêmica. Bush precisou usar uma medida de exceção chamada "indicação de recesso", para obter sua efetivação no cargo já que 102 embaixadores já haviam assinado uma petição para que 0 Senado não aceitasse a nomeação de Bolton. Com a vitória dos democratas nas eleições do final de 2006, a situação de Bolton

tornou-se insustentável. Bush não mostrou disposição para bancar sua permanência no cargo diante da oposição.

Assim, o embaixador pediu sua saída em dezembro, um mês antes do fim de seu mandato. Essa perda fez parte do quadro de crise de governabilidade de Bush na metade de seu segundo mandato (U.S. ENVOY REFUSES EXIT COMMENT, 2006

9. Em 8 de abril de 2008, o novo Representante Permanente dos Estados Unidos na ONU, Zalmay Khalilzad, declarou que seu Estado não enviaria aos fundos da organização em 2008 quantia referente

ao que seria aplicado no Conselho. Khalilzad ocupou o cargo de 23 de abril de 2007 até 0 fim da gestão W. Bush, em janeiro de 2009. 0 Embaixador possuía grande experiência e prestígio, tendo sido embaixador para o Iraque de 2005 a 2007 e para o Afeganistão, de 2003 a

2005. Apesar de ser menos polêmico que Bolton, Khaliizad também se envolveu na Guerra contra o Terror e compunha a linha dos neoconservadores. tões e interesses políticos dos Estados. Não obtendo êxito nesse sentido, o que é pouco surpreendente, tendo em vista a natureza estruturalmente política dos relacionamentos internacionais, tanto o ambiente do $\mathrm{CDH}$ quanto o exercício da RPU são permeados pela politização. Sendo assim, ensejam ou incitam, para usar os termos de Forsythe (2011), uma atuação pragmática e casuística por parte dos EUA. Portanto, é nesse ambiente altamente politizado que os EUA ingressam a partir de 2009 e passam pelas suas respectivas revisões em 2010 e 2015. Mas antes disso, é preciso compreender a relação tensa que o governo Bush manteve durante as negociações e primeiros anos de funcionamento do $\mathrm{CDH}$.

Os Estados Unidos na criação, consolidação e boicote ao Conselho de Direitos Humanos (2005-2008)

O relatório da Assembleia Geral das Nações Unidas (AGNU) "Um mundo mais seguro: nossa responsabilidade compartilhada" (A/59/565) foi divulgado no final de 2004. O documento foi produzido pelo "Painel de Alto Nível sobre ameaças, desafios e mudanças", convocado pelo Secretário Geral Kofi Annan, em 2003, com o intuito de mapear e promover os rumos das futuras reformas da ONU. O foco principal desse fórum, vale ressaltar, era a questão da segurança coletiva, entretanto, a área de direitos humanos também estava incluída nos debates (BELLI, 2008/2009). A proposta propriamente dita de criação do Conselho de Direitos Humanos, em substituição à Comissão de Direitos Humanos, originou-se na delegação suíça, por meio do Conselheiro Federal Calmy-Rey, um dos membros do Painel (MULLER, 2006; KNIGHT, 2005).

Em 15 de Março de 2006, seria aprovado pela AGNU o projeto de resolução que substituía a Comissão pelo Conselho (UNITED NATIONS, 2006a). O projeto foi aprovado com 170 votos, e recebeu quatro votos contrários, sendo um deles justamente o da delegação dos EUA, além de Israel, Ilhas Marshall e Palau ${ }^{7}$. O Embaixador dos EUA, John Bolton, justificou o posicionamento de seu país invocando uma "questão de princípio". Segundo ele, não havendo mecanismos efetivos que garantissem a credibilidade de seus membros, os Estados Unidos não viam avanço do Conselho em relação à Comissão anterior (UNITED NATIONS, 2006b).

A análise da postura dos EUA naquele momento em relação ao $\mathrm{CDH}$ e à ONU é indissociável das características de suas lideranças diplomáticas naquele contexto. De 2005 a 2006, o Representante Permanente dos EUA para as Nações Unidas foi o Embaixador John Bolton ${ }^{8}$, reconhecidamente grande crítico da ONU. Bastante polêmico, Bolton não se sustentou muito tempo no cargo, sendo substituído, em 2007 por Zalmay Khalilzad' ${ }^{9}$ figura neoconservadora pouco afeita ao engajamento multilateral (U.S. ENVOY REFUSES EXIT COMMENT, 2006). Ademais, de 2006 a 2008, o Embaixador dos Estados Unidos em Genebra para as Nações Unidas e outras Organizações Internacionais foi Warren W. Tichenor, que avistava a ONU primordialmente como um palco da liderança americana no mundo (TICHENOR, 2006). Tais indicações contribuíram para constituir um papel combativo dos EUA em relação ao CDH durante a administração Bush. Mas além da "questão de princípio", 
explicitada por Bolton, as derrotas da delegação dos EUA no processo de construção do $\mathrm{CDH}$ foram indicadas como justificativas para seu voto contrário. Acerca da composição do $\mathrm{CDH}$, por exemplo, a proposta dos EUA era que os membros deveriam ser eleitos por dois terços da AGNU. Contudo, a proposta aprovada foi a de maioria simples (BLANCHFIELD, 2006). A delegação dos EUA, além disso, advogava que o $\mathrm{CDH}$ deveria ter, no máximo, vinte membros e não os 53 da extinta Comissão. Todavia, a redução foi apenas de 53 para 47 membros $^{10}$.

Os EUA também não conseguiram aprovar restrição para que Estados considerados violadores sistemáticos dos direitos humanos (como Sudão e Líbia) tivessem cadeiras no $\mathrm{CDH}$. A delegação dos EUA também sugeriu um exclusionary criteria. Se aprovado, esse dispositivo faria com que Estados que estivessem sob sanção do Conselho de Segurança (CS) por abusos contra os direitos humanos ou atos terroristas se tornassem inelegíveis a cadeiras do Conselho (BLANCHFIELD, 2006).

Afora essa estratégia restritiva, os EUA tentaram aprovar mecanismos institucionais que garantiriam sua própria eleição como membro do $\mathrm{CDH}$ com maior facilidade. Nesse sentido, também foram malsucedidos na tentativa de aprovar uma fórmula que permitiria reeleição ilimitada e cadeiras garantidas para os cinco membros permanentes do CS (BLANCHFIELD, 2006; BELLI, 2008/2009). A delegação dos EUA teve problemas também com o fato de que o grupo que abrangia a Europa e "outros países" (grupo em que os EUA estariam) foi o mais afetado pela redução da quantidade de membros da Comissão para o Conselho, com número de cadeiras alterado de dez para sete.

Com o voto contrário dos EUA, em 22 de março, o ECOSOC extinguia a Comissão de Direitos Humanos, que deixaria de existir em 16 de junho para, no dia 19, o Conselho ter sua primeira sessão ${ }^{11}$. Os EUA, apesar de sua oposição ao $\mathrm{CDH}$, participaram como observadores nos três anos em que lá estiveram durante a presidência de Bush.

As principais mudanças com a criação do Conselho foram as reuniões mais frequentes, ao longo de todo o ano, e ainda podendo ser convocadas sessões extraordinárias; as possibilidade de suspensão dos membros que cometam violações sistemáticas dos direitos humanos; a equiparação da importância institucional da temática dos direitos humanos dentro da ONU diante das questões de paz e segurança e desenvolvimento; e, seguramente a maior novidade, a adoção do mecanismo de Revisão Periódica Universal (RPU), o qual prevê a análise periódica da situação dos direitos humanos de todos os membros da ONU ao longo de quatro anos e meio (ANNAN, 2005). Contudo, o novo órgão herdou como grande desafio conseguir a adesão das principais potências, entre as quais se destacam os EUA.

Em maio de 2006, foram realizadas as primeiras eleições para o $\mathrm{CDH}$, e, em abril de 2006, o governo dos EUA manifestou publicamente sua vontade de não concorrer a um lugar no CDH. Blanchfield (2006) apresenta duas justificativas para esse posicionamento: segundo a primeira, os EUA teriam dado preferência à candidatura de outros Estados de seu grupo (que compartilhavam com a Europa) que tinham votado a favor da criação do $\mathrm{CDH}$. Conforme a outra, que acreditamos ser mais
10. $0 \mathrm{CDH}$ é integrado por 47 membros, eleitos segundo distribuição geográfica equitativa, de forma direta e individual em votação secreta pela maioria dos membros da Assembleia Geral, para um mandato de três anos, sendo no máximo dois mandatos consecutivos (UNITED NATIONS, 2006a).

11. Analogamente à Comissão, o Conselho deveria: analisar violações, promover assistência e educação na área, esforçar-se para evitar abusos, responder a situações de emergência e servir de fórum internacional para o diálogo sobre questões de direitos humanos. Entre as permanências da Comissão no Conselho estão a adoção da Declaração Universal de Direitos Humanos e de outros tratados essenciais para a proteção das liberdades fundamentais; a utilização de mecanismos especiais (peritos independentes e relatores especiais); e a participação de ONGs e outros observadores (DURAN, 2006; SHORT, 2008). Os observadores tinham direito de participar das reuniões anuais da Comissão assistindo e fazendo falas. 
12. Prova disso é a produção de relatórios anuais detalhados a pedido do Congresso sobre a relação entre os Estados Unidos e o órgão desde 2006 , organizado por Luisa Blanchfield.

13. 0 boicote orçamentário dos EUA ao CDH foi aprovado tanto na Câmara quanto no Senado. Na Câmara votaram

241 a favor e 178 contra. Entre os favoráveis, 210 eram democratas e 31 republicanos. Entre aqueles que se posicionaram contrariamente, 14 eram democratas e 164 republicanos. Além disso, houve 13 abstenções, 7 democratas e 6 republicanos. No Senado (no

qual uma resolução é aprovada com maioria simples), foram 81 votos a favor - sendo 44 democratas, 35 republicanos, 2 independentes -12 contrários todos republicanos - e 7 abstenções - 2 republicanos e 5 democratas. Digno de ressaltar o fato de entre os senadores que se abstiveram, estava Barack Obama, então senador democrata pelo estado de Illinois. Os dados das votações estão disponíveis nos links a seguir: U.S. House of Representatives Roll Call 542, 110th Congress. Disponível em: <http:// clerk.house.gov/evs/2007/roll542.xml>;

e U.S. Senate Roll Call Votes 110th

Congress, 1st Session. Disponível em:

$<$ http://www.senate.gov/legislative/ LIS/roll_call_lists/roll_call_vote_cfm.cf $\mathrm{m}$ ? congress $=110 \&$ session $=1$ \& vote $=003$ 25\#name>. plausível, os EUA teriam preferido não concorrer à eleição por recear não receber os votos necessários para se eleger naquele momento.

Estando de fora, os EUA participaram das sessões do primeiro ano de atividades do $\mathrm{CDH}$ como observadores somente. Nessa condição, a delegação tinha direito à voz e à emissão de propostas, mas não a voto. Entendemos o fato de não poder votar como ponto de relativa vulnerabilidade para os EUA, já que acabaram por perder influência no $\mathrm{CDH}$ nessa importante fase de construção institucional e consolidação política.

Alguns governos se mostraram desapontados com o voto contrário dos EUA à criação do $\mathrm{CDH}$. Em relação às eleições, representantes de países aliados, como o Reino Unido, demonstraram apoio à candidatura dos EUA naquele momento ou posterior. No entanto, Estados opositores, como Cuba, interpretaram a recusa dos EUA em concorrer como uma espécie de confissão de culpa pelas violações de direitos humanos em Guantánamo e Abu Graib.

$\mathrm{Na}$ esfera doméstica, o Congresso dos EUA acompanhava com atenção desde o início as discussões para a criação do $\mathrm{CDH}^{12}$. As opiniões dos parlamentares sobre a não candidatura eram divergentes. De um lado, estava a percepção de que o afastamento mostrava um sinal de isolamento (como a do Representante Tom Lantos (D-CA)). Do outro lado, estavam os que entendiam a postura como necessária para que os EUA não tivessem sua credibilidade subtraída (como declarou o Senador Bill Frist (R-TN)) (BLANCHFIELD, 2008).

Conforme o tempo passava e as demandas dos EUA não eram contempladas, sua relação com o CDH se complicava e o teor crítico dos discursos aumentava. Mantendo a orientação da política externa, em seis de março de 2007, o governo declarou novamente que os EUA não concorreriam a um assento no CDH. O porta-voz do Departamento de Estado afirmou que o Conselho não estava inspirando credibilidade, citando um foco excessivo em Israel e a desatenção a violadores como Cuba, Burma e Coreia do Norte (MCCORMACK, 2007). É relevante ressaltar que essas duas justificativas estariam na base do boicote orçamentário que pouco tempo depois os EUA dispensariam ao $\mathrm{CDH}$.

Apesar do anúncio de que não concorreriam uma vez mais nas eleições de maio, o governo dos EUA ainda permanecia enviando suas contribuições orçamentárias para a $\mathrm{ONU}$, inclusive a parcela referente ao CDH. Blanchfield (2008) afirma que, em julho de 2007, representantes da Administração Bush veicularam que, apesar da decepção quanto ao $\mathrm{CDH}$, continuariam financiando-o.

Entretanto, contrariando essa posição, em 26 de dezembro de 2007, o Congresso apresentou o Consolidated Appropriations Act para o ano de 2008 (UNITED STATES, 2007a) com uma cláusula indicando boicote orçamentário ao CDH. Em oito de abril de 2008, Zalmay Khalilzad, o novo Representante Permanente dos Estados Unidos na ONU, declarou que o país não enviaria aos fundos da ONU em 2008 a quantia referente ao que seria aplicado no $\mathrm{CDH}^{13}$. E em maio de 2008, os EUA não concorreram de novo nas eleições por um assento no órgão (KHALILZAD, 2008).

No mês seguinte, o distanciamento entre o Governo Bush e o CDH chegou ao seu ápice. Em seis de junho, o porta-voz do Departamento de 
Estado anunciou que os EUA somente fariam parte do CDH quando fosse comprovado que tal entrada atenderia estritamente o interesse nacional dos EUA. Ademais, voltou a criticar o que chamou de "foco excessivo do órgão em Israel”, o qual já mencionamos acima como ponto primordial de discordância ${ }^{14}$.

Tabela 1 - Número total de recomendações feitas pelos membros permanentes do Conselho de Segurança.

\begin{tabular}{c|c|c|c|c|c}
\hline Sessão & EUA & China & Rússia & Reino Unido & França \\
\hline 1 & 2 & 2 & 18 & 26 & 14 \\
\hline 2 & 18 & 1 & 9 & 50 & 27 \\
\hline 3 & 0 & 5 & 5 & 54 & 61 \\
\hline 4 & 0 & 8 & 13 & 58 & 58 \\
\hline 5 & 40 & 2 & 10 & 56 & 50 \\
\hline
\end{tabular}

Fonte: Elaborado pelos autores com os dados extraídos de UPR-Info, (2017)

As divergências entre a administração Bush e o $\mathrm{CDH}$ são claras quando observamos o histórico de recomendações feitas pelos EUA nas primeiras sessões da RPU. Vemos que nas primeiras sessões, de abril e maio de 2008, os EUA, enquanto observadores, fizeram um total de 20 recomendações, enquanto que outros países do Conselho de Segurança, como Reino Unido e França apresentaram um grau maior de engajamento com um total de 76 e 41 recomendações respectivamente. O desengajamento foi a estratégia utilizada pelos EUA nessas primeiras sessões e a decisão de junho de 2008 reflete-se nos números da terceira e quarta sessões da RPU.

Observa-se, portanto, que a chamada politização, que justificou, na visão dos EUA, a reforma da Comissão e o boicote ao $\mathrm{CDH}$, também esteve presente na própria postura de enfrentamento dos EUA ao $\mathrm{CDH}$. A motivação da posição do governo Bush foi essencialmente política, chegando ao seu esplendor quando o Departamento de Estado pragmaticamente anunciou, conforme dito acima, que o país só adentraria o órgão quando isso atendesse ao seu interesse nacional. A partir dessa chave de leitura, o governo Obama parece ter pragmaticamente conectado a satisfação dos interesses políticos dos EUA não ao boicote ao $\mathrm{CDH}$, mas ao engajamento.

A entrada dos Estados Unidos no Conselho de Direitos Humanos (2009).

Ao longo da administração Bush, os EUA se afastaram explicitamente dos temas multilaterais, em prejuízo do engajamento em regimes e instituições internacionais. Nesse contexto, o democrata Barack Obama se apresentou como uma promessa de reversão desse cenário e assim venceu as eleições presidenciais de 2008. Já em seu discurso de posse, Obama afirmou que as necessidades de segurança não iriam fazer com que os valores dos EUA fossem negligenciados por conveniência, e, como tal, que os direitos humanos seriam assegurados (OBAMA, 2009).

Quanto à seleção de quadros diplomáticos que se relacionariam com a ONU na gestão Obama, em 22 de janeiro de 2009, foi aprovada por unanimidade pelo Senado a indicação da Embaixadora Susan Rice ${ }^{15}$ como
14. Como já mencionado, um dos grandes motivos pelos quais os EUA não viam com bons olhos o recém-criado CDH era a permanência de Israel na agenda do órgão. Prova desse desagrado foi a elaboração de uma resolução condenatória pela Câmara dos Representantes a esse posicionamento do Conselho em setembro de 2007. Essa resolução, H.R. 557, introduzida pelo House Foreign Affairs Committee, foi proposta por dois deputados da Califórnia, John Campbell e Howard Berman, o primeiro, republicano, e o segundo, democrata. A resolução centra sua crítica na ênfase demasiada que o CDH estaria dando a Israel em detrimento da atenção concedida a outros países violadores de direitos humanos (UNITED STATES, 2007c).

15. Rice integrou a campanha de Obama como Conselheira Sênior para Negócios de Segurança Nacional e, após sua eleição, integrou seu Gabinete. Antes disso, Rice foi scholar no Conselho de Segurança Nacional e Secretária Assistente no Departamento de Estado (UNITED STATES, 2009). 
Representante Permanente para as Nações Unidas. Diferente de Bolton e Khalilzad, Rice explicitou sua crença de que a ONU tem papel essencial na consecução da paz e da segurança global. Além disso, engrossou o discurso de Obama de que os EUA precisavam retomar seu engajamento multilateral e de que as organizações internacionais deveriam ser reformadas por dentro, e não contestadas de fora (UNITED STATES, 2009).

Seguindo essa linha de orientação, a chegada de Obama à Casa Branca, em 2009, gerou uma rota de alteração das políticas dos EUA para o CDH. Em fevereiro do mesmo ano, Obama fez o anúncio de que os EUA participariam como observadores na $10^{a}$ sessão do Conselho, que ocorreria em março daquele ano (BLANCHFIELD, 2009). Esse pronunciamento já assinalava nova aproximação com o órgão, considerando que a delegação dos EUA havia se retirado no meio das duas sessões anteriores. Um passo mais notório foi dado em 31 de março de 2009, quando o Presidente anunciou que os EUA concorreriam a um assento no $\mathrm{CDH}$.

Tabela 2 - Número total de recomendações feitas pelos membros permanentes do Conselho de Segurança.

\begin{tabular}{|c|c|c|c|c|c|}
\hline Sessão & EUA & China & Rússia & Reino Unido & França \\
\hline 4 & 0 & 8 & 13 & 58 & 58 \\
\hline 5 & 40 & 2 & 10 & 56 & 50 \\
\hline 6 & 60 & 3 & 10 & 60 & 65 \\
\hline 7 & 63 & 3 & 13 & 58 & 58 \\
\hline 8 & 41 & 16 & 15 & 43 & 69 \\
\hline 9 & 49 & 11 & 7 & 53 & 64 \\
\hline 10 & 58 & 18 & 28 & 63 & 75 \\
\hline 11 & 64 & 5 & 22 & 66 & 83 \\
\hline 12 & 70 & 4 & 23 & 60 & 79 \\
\hline 13 & 41 & 13 & 23 & 24 & 59 \\
\hline 14 & 43 & 22 & 16 & 26 & 55 \\
\hline 15 & 38 & 14 & 11 & 27 & 65 \\
\hline 16 & 40 & 25 & 33 & 29 & 76 \\
\hline 17 & 45 & 19 & 26 & 30 & 103 \\
\hline 18 & 38 & 21 & 18 & 28 & 75 \\
\hline 19 & 42 & 28 & 38 & 28 & 86 \\
\hline 20 & 41 & 19 & 37 & 28 & 67 \\
\hline 21 & 42 & 24 & 35 & 28 & 76 \\
\hline 22 & 35 & 32 & 31 & 28 & 87 \\
\hline 23 & 44 & 18 & 16 & 28 & 90 \\
\hline 24 & 41 & 21 & 29 & 28 & 82 \\
\hline 25 & 42 & 25 & 7 & 29 & 84 \\
\hline TOTAL & 997 & 351 & 461 & 878 & 1606 \\
\hline
\end{tabular}

Fonte: Elaborado pelos autores com os dados extraídos de UPR-Info, (2017)

A quarta sessão da RPU, em fevereiro de 2009, ocorreu poucos dias após Obama assumir a presidência, e sua administração teve que lidar com o custo do desengajamento da administração Bush. Muito embora Obama tenha declarado sua adesão ao órgão, somente a partir da quinta sessão, 
ainda como observador, é que os EUA voltam a fazer recomendações. A atuação americana, neste quesito, passa a acompanhar o padrão dos outros membros ocidentais do Conselho de Segurança. A volta na participação da RPU torna-se um primeiro passo para a eleição como membro permanente.

Assim, em 19 de maio, os EUA se tornaram então membros do $\mathrm{CDH}$, alcançando uma das três vagas do grupo que inclui "Estados da Europa Ocidental e outros Estados". A eleição em si não foi dura, já que havia só três candidatos e os EUA só precisavam de maioria simples, ou seja, 97 votos da AGNU. Entretanto, a despeito de obterem o objetivo com folga (167 votos), receberam dez votos a menos que a Bélgica e doze a menos que a Noruega, os outros dois Estados eleitos no mesmo grupo.

O resultado da votação demonstrou que a efetivação da inserção dos EUA poderia demandar mais vontade política do que o governo esperava. Os EUA haviam enfrentado muitos problemas com a antiga Comissão e com o novo $\mathrm{CDH}$. Ademais, as políticas contraproducentes na área dos direitos humanos, especialmente ligadas à chamada Guerra ao Terror, foram bastante danosas para a imagem desse país no sistema de direitos humanos da ONU. Tudo isso fomentou uma grande desconfiança, que não seria automaticamente dissipada apenas com a sinalização do interesse de Obama em reverter as políticas de Bush.

Eileen Donahoe, que tem formação acadêmica e profissional voltada às instituições internacionais e conhecedora do processo de reforma da $\mathrm{ONU}^{16}$, foi a selecionada por Obama para substituir Tichenor como Embaixadora dos Estados Unidos em Genebra para as Nações Unidas e outras Organizações Internacionais, a partir de janeiro de 2009. Conquistado o assento do CDH, a Embaixadora foi nomeada a primeira Representante Permanente dos Estados Unidos para o órgão (UNITED STATES, 2010). Assim, o retorno dos EUA ao CDH e a escolha do staff parecem sugerir alguma diferença do perfil de Obama em relação à ONU em 2009 quando comparado ao seu antecessor.

O novo status de membro do $\mathrm{CDH}$ trouxe consigo também implicações financeiras para os EUA. A provisão orçamentária dos EUA para 2009 continuava indicando boicote orçamentário ao Conselho (UNITED STATES, 2008). Porém, como obtiveram uma cadeira no CDH, satisfizeram o requisito para que a medida deixasse de ser aplicada ${ }^{17}$ e, desse modo, os recursos voltaram a ser enviados ainda em 2009.

É relevante dizer que as medidas de aproximação dos Estados Unidos com o $\mathrm{CDH}$ não se deveram a algum tipo de persuasão do presidente Obama junto ao Congresso. O Congresso continuou extremamente reticente ao $\mathrm{CDH}$ e permaneceu firme na sua recomendação de boicote orçamentário e seus posicionamentos pró-Israel. Para alguns, a não participação dos EUA nos primeiros anos do Conselho está relacionada também ao receio da administração Bush de que as atividades relacionadas com o 11/9 pudessem ser alvo de críticas internacionais (FREEDMAN, 2009, p. 27-28). Obama foi, na realidade, favorecido pelas cláusulas da própria resolução do boicote: ao se candidatar à cadeira e ser eleito, tornou inócuo o bloqueio orçamentário. Seu novo desafio político agora seria ver a situação de direitos humanos dos EUA passar pela análise de outros Estados no âmbito do novidadeiro mecanismo de Revisão Periódica Universal.
16. Donahoe tem estudos focados no uso da força, na reforma da ONU e em direito internacional, além de experiência em organizações de direitos humanos. Seu posto anterior havia sido de Scholar Afiliada ao Centro de Segurança Internacional e Cooperação na Universidade de Stanford.

17. De acordo com o texto: “The provision specified that it shall not apply if (1) the Secretary of State certifies to the Committees on Appropriations that funding the Council is in the national interest of the United States or (2) the United States is a member of the Human Rights Council" (H.R. 1105, sessão 7053). 
Outro custo do desengajamento de Bush está nos países que fizeram recomendações aos EUA durante o primeiro ciclo. Verificamos que as maiores contribuições vieram dos Estados considerados do "Eixo do Mal” pela administração Bush. Em contrapartida, o segundo ciclo apresenta uma quantidade maior de recomendações direcionadas para os EUA de outros grupos. Neste caso, apresentaram em torno de 108 recomendações a mais, somando um total de 388 recomendações, conforme a tabela abaixo. No primeiro ciclo, os três países que fizeram o maior número de recomendações foram: Venezuela (19), Irã (16) e Cuba (14).

Tabela 3 - 0s 10 países que mais realizaram recomendações aos EUA no Primeiro Ciclo

\begin{tabular}{c|c|c|c}
\hline Rank & $\begin{array}{c}\text { Estado que } \\
\text { Recomenda }\end{array}$ & $\begin{array}{c}\text { Total de } \\
\text { Recomendações }\end{array}$ & $\begin{array}{c}\text { \% das 280 } \\
\text { Recomendações }\end{array}$ \\
\hline 1 & Venezuela & 19 & 6.79 \\
\hline 2 & Irã & 16 & 5.71 \\
\hline 3 & Cuba & 14 & 5 \\
\hline 4 & Bolívia & 12 & 4.29 \\
\hline 5 & Coreia do Norte & 11 & 3.93 \\
\hline 6 & Áustria & 11 & 3.93 \\
\hline 7 & Egito & 10 & 3.57 \\
\hline 8 & Nicarágua & 8 & 2.86 \\
\hline 9 & Noruega & 8 & 2.86 \\
\hline 10 & Brasil & 7 &
\end{tabular}

Fonte: Elaborado pelos autores com os dados extraídos de UPR-Info, (2017)

Ao lidar com a herança da administração Bush, vemos que no campo dos direitos humanos o governo Obama foi forçado a lidar com o passado e responder internacionalmente pelas opções feitas pelo seu antecessor. Tal situação não foi a mesma no segundo ciclo. Vemos que há uma nova distribuição entre os países que mais recomendaram, inclusive com maior recomendação de países do Conselho de Segurança, apesar da relativa manutenção da posição venezuelana.

Tabela 4 - Os 10 países que mais realizaram recomendações aos EUA no Segundo Ciclo

\begin{tabular}{c|c|c|c}
\hline Rank & $\begin{array}{c}\text { Estado que } \\
\text { Recomenda }\end{array}$ & $\begin{array}{c}\text { Total de } \\
\text { Recomendações }\end{array}$ & $\begin{array}{c}\text { \% das 388 } \\
\text { Recomendações }\end{array}$ \\
\hline 1 & França & 10 & 2.58 \\
\hline 2 & Venezuela & 10 & 2.58 \\
\hline 3 & Maldivas & 10 & 2.58 \\
\hline 4 & Egito & 9 & 2.32 \\
\hline 5 & Federação Russa & 9 & 2.32 \\
\hline 6 & China & 8 & 2.06 \\
\hline 7 & Azerbaijão & 8 & 2.06 \\
\hline 8 & Bolívia & 7 & 1.8 \\
\hline 9 & Paquistão & 7 & 1.55 \\
\hline 10 & Canadá & 6 & \\
\hline
\end{tabular}

Fonte: Elaborado pelos autores com os dados extraídos de UPR-Info, (2017) 
Neste caso, a França figura entre os países que mais recomendaram aos EUA no segundo Ciclo. Isso evidencia uma divergência em relação à literatura sobre o $\mathrm{CDH}$, segundo a qual na RPU os aliados procuram se blindar (FREEDMAN, 2009, p. 308). Ainda que não seja uma tendência verificável no plano universal, no caso americano, essa alteração é visível e cabem maiores investigações a respeito. A relação entre engajamento e desengajamento dos EUA demonstra a politização das atividades no $\mathrm{CDH}$. O desengajamento tanto no plano financeiro (boicote orçamentário) quanto no plano político (a não participação no Conselho) por um período gerou graves custos para os EUA. Isso ficou patente no padrão dos Estados que fizeram recomendações no primeiro ciclo da RPU pelo qual os EUA passaram.

A politização do mecanismo, entretanto, apresenta outras facetas, entre as quais a forma como o Estado sob revisão rejeita as recomendações, e os temas presentes nas recomendações. Quanto ao primeiro caso, faz-se necessário tratar das definições de "Accepted" e "Noted", opções binárias disponíveis ao Estados sob revisão ao reagir às recomendações recebidas. Essas são as nomenclaturas previstas na Resolução 5/1 §32, de 2007, a resolução que normatizou, após longa negociação entre os Estados (da qual os EUA estiveram ausentes), o funcionamento do Conselho logo após a sua criação. Conforme o $§ 32$ (tradução nossa): "Recomendações que gozam do apoio do Estado em questão serão identificadas como tal. Outras recomendações, juntamente com as observações do Estado em questão, serão anotadas. Ambos serão incluídos no relatório final a ser adotado pelo Conse1 ho ${ }^{18}$." No caso do primeiro ciclo, por exemplo, os EUA tiveram uma média de $30 \%$ de rejeições, independentemente da região da qual adveio a recomendação.

Tabela 5 - Relação entre Continente e a resposta dada pelos EUA no Primeiro Ciclo

\begin{tabular}{|c|c|c|c|c|}
\hline Continente & $\begin{array}{c}\text { Tipo de } \\
\text { Resposta } \\
\text { possível }\end{array}$ & $\begin{array}{l}\text { Total por tipo de } \\
\text { resposta }\end{array}$ & Totais & $\%$ parcial \\
\hline \multirow{2}{*}{ América Latina } & Noted & 33 & \multirow{2}{*}{92} & 35.86957 \\
\hline & Accepted & 59 & & 64.13043 \\
\hline \multirow{2}{*}{ Europa } & Noted & 32 & \multirow{2}{*}{72} & 44.44444 \\
\hline & Accepted & 40 & & 55.55556 \\
\hline \multirow{2}{*}{ Ásia } & Noted & 17 & \multirow{2}{*}{70} & 24.28571 \\
\hline & Accepted & 53 & & 75.71429 \\
\hline \multirow{2}{*}{ África } & Noted & 12 & \multirow{2}{*}{34} & 35.29412 \\
\hline & Accepted & 22 & & 64.70588 \\
\hline \multirow{2}{*}{ Oceania } & Noted & 3 & \multirow{2}{*}{11} & 27.27273 \\
\hline & Accepted & 8 & & 72.72727 \\
\hline \multirow{2}{*}{ Canadá } & Noted & 0 & \multirow{2}{*}{1} & 0 \\
\hline & Accepted & 1 & & 100 \\
\hline \multirow{2}{*}{ Parciais } & Noted & 97 & \multirow{2}{*}{280} & 34.64286 \\
\hline & Accepted & 183 & & 65.35714 \\
\hline
\end{tabular}

Fonte: Elaborado pelos autores com os dados extraídos de UPR-Info, (2017
18. "Recommendations that enjoy the support of the State concerned will be identified as such. Other recommendations, together with the comments of the State concerned thereon, will be noted. Both will be included in the outcome report to be adopted by the Council." 
19. No caso brasileiro, por exemplo, 0 país fez uma única rejeição no primeiro ciclo em 25 de maio de 2012. Neste caso, o Brasil rejeitou a recomendação feita pela Dinamarca de acabar com a separação entre as polícias civis e militares a fim diminuir a incidência de execuções extrajudiciais em território brasileiro. Neste caso, o documento $\mathrm{A} /$ HRC/21/11/Add.1 relata que "Recommendation No. 60 cannot enjoy the support of Brazil, in light of the constitutional provision on the existence of civilian and military police forces". Reparamos que não há um marcador da rejeição do governo brasileiro à recomendação da Dinamarca. Assim também está expresso no "Matrices of recommendations" no qual a rejeição é marcada pela expressão Noted, conforme pode se observer no seguinte link abaixo: http://lib ohchr.org/HRBodies/UPR/Documents/ session13/BR/MatriceBrazil.docx.
No caso da elaboração da base de dados pela UPR-Info, ONG que se dedica à sistematização do mecanismo, Accepted é a classificação recebida por toda recomendação que claramente usa o termo "aceito". Qualquer outra forma de reconhecimento da recomendação é marcada como Noted. Caso uma aceitação parcial seja motivada, a recomendação é separada em duas sendo a parte aceita marcada como Accepted, enquanto que a parte rejeitada será marcada como Noted (UPR-INFO, 2014b). O Noted é uma nuance muito interessante do processo da RPU (e que certamente merece uma pesquisa mais específica e aprofundada). Politicamente, o Noted é um meio-termo entre a rejeição e a aceitação, isto é, ao assinalar Noted, o posicionamento estatal ocupa uma zona nebulosa entre a não aceitação e a não rejeição. Por isso, aos olhos dos Estados, ele é uma nomenclatura interessante, pois muitas vezes suaviza os efeitos de constrangimentos de não aceitar determinadas recomendações. Segundo Paulo Lugon Arantes, representante da ONG brasileira Conectas Direitos Humanos em Genebra, entrevistado pelos autores deste artigo, no transcorrer das rodadas da RPU, os Estados variavam demais na linguagem que utilizavam ao não aceitar recomendações ${ }^{19}$. Sendo assim, em 2014 o Alto Comissariado para Direitos Humanos, que funciona como staff do Conselho, fez um movimento para que as delegações respeitassem a resolução de 2007 e utilizassem Accepted e Noted apenas.

Tendo em vista o maior engajamento dos EUA no mecanismo e o aprendizado institucional que a participação gera, observa-se, na tabela abaixo, que, no segundo ciclo, os EUA rejeitaram mais de 50\% das recomendações recebidas.

Tabela 6 - Relação entre Continente e a resposta dada pelos EUA no Segundo Ciclo.

\begin{tabular}{|c|c|c|c|c|}
\hline Região & $\begin{array}{l}\text { Tipo de } \\
\text { Resposta } \\
\text { possível }\end{array}$ & $\begin{array}{l}\text { Total por } \\
\text { tipo de } \\
\text { resposta }\end{array}$ & Totais & $\%$ parcial \\
\hline \multirow{2}{*}{ América Latina } & Noted & 50 & \multirow{2}{*}{72} & 69.44444 \\
\hline & Accepted & 22 & & 30.55556 \\
\hline \multirow{2}{*}{ Europa } & Noted & 67 & \multirow{2}{*}{111} & 60.36036 \\
\hline & Accepted & 44 & & 39.63964 \\
\hline \multirow{2}{*}{ Ásia } & Noted & 55 & \multirow{2}{*}{114} & 48.24561 \\
\hline & Accepted & 59 & & 51.75439 \\
\hline \multirow{2}{*}{ África } & Noted & 35 & \multirow{2}{*}{77} & 45.45455 \\
\hline & Accepted & 42 & & 54.54545 \\
\hline \multirow{2}{*}{ Oceania } & Noted & 6 & \multirow{2}{*}{8} & 75 \\
\hline & Accepted & 2 & & 25 \\
\hline \multirow{2}{*}{ Canadá } & Noted & 0 & \multirow{2}{*}{6} & 0 \\
\hline & Accepted & 6 & & 100 \\
\hline \multirow{2}{*}{ Parciais } & Noted & 213 & \multirow{2}{*}{388} & 54.89691 \\
\hline & Accepted & 175 & & 45.10309 \\
\hline
\end{tabular}

Fonte: Elaborado pelos autores com os dados extraídos de UPR-Info, (2017)

Ao contrário do que poderia prever uma leitura tradicional que vê uma dinâmica de puro enfrentamento na relação entre Estado e sociedade civil, o Noted não é malvisto pelos ativistas que atuam no Conse- 
lho em Genebra. Segundo novamente Paulo Lugon Arantes, aos olhos dos ativistas e do próprio staff do Conselho, o Noted não significa necessariamente uma rejeição a uma recomendação. Na medida em que ele não comunica isso de forma precisa, ele se torna uma brecha para que as organizações continuem pressionando - interna e externamente - 0 Estado em questão a converter aquele Noted em aceitação na prática, isto é, na implementação da recomendação, a despeito de não a ter aceitado explicitamente no momento da RPU. É claro que isso não impede que os membros da sociedade civil também interpretem o Noted como uma linguagem diplomática da qual os Estados se valem para eventualmente mascarar rejeições a recomendações.

Os poucos trabalhos acadêmicos sobre o assunto, entretanto, não fazem maiores debates sobre a questão (COCHRANE; MCNEILLY, 2013; COX, 2010; MCMAHON; ASCHERIO, 2012). Por isso, certamente, esta é outra agenda de pesquisa muito interessante a ser perseguida futuramente, incluindo o papel do Noted enquanto mecanismo de politização da RPU. O que observamos neste momento é que houve uma curva de aprendizado, pelos EUA, de como o mecanismo funciona, o que levou a um aumento no número de rejeições. O que se destaca, neste caso, é, usando os termos de Forsythe (2011), o relativo cosmopolitismo wilsoniano com o qual os EUA regressam ao Conselho e ao mecanismo do RPU no primeiro mandato do presidente Obama e como o pragmatismo casuístico se desenvolve a partir do segundo ciclo.

A segunda faceta da politização da RPU refere-se aos temas presentes nas recomendações. No caso dos EUA, a distribuição temática das recomendações recebidas incide de forma representativa sobre a forma excepcionalista da política externa de direitos humanos do país. Neste contexto, o UPR-Info apresenta uma categorização dos temas apresentados em cada RPU, totalizando 56 categorias diferentes. Para a análise dos dados, primeiramente, procura-se marcar todas as questões consideradas importantes, como qualquer menção a procedimentos especiais, comitês de tratados (ou organizações internacionais), instrumentos ou obrigações internacionais, violações de direitos humanos causados por agente estatal específico, sociedade civil, condições das detenções, tortura, execuções extrajudiciais e desaparecimentos forçados. Além disso, nos casos em que há mais de uma violação de direitos humanos as categorias passam a derivar não dos temas da violação, mas dos grupos violados, isto é, as vítimas. Recomendações sobre violações de direitos de moradia e educação de um grupo social específico, por exemplo, são categorizadas como "Minorias", e não pelas violações individuais. Caso apresente uma violação e uma vítima, ambas são apresentadas.

Um grupo importante é o dos instrumentos internacionais. Este tema apresenta-se em dois grupos distintos, um mais amplo (Instrumentos Internacionais) e outro mais específico (quando se refere ao tema do tratado). Essas recomendações são referentes à ratificação de tratados internacionais (UPR-INFO, 2016). O modelo excepcionalista dos EUA lida com a perspectiva segundo a qual os elementos nacionais de direitos humanos dos EUA são superiores a todos os outros sistemas nacionais e, como tais, devem ser exportados e copiados pelas outras nações. 
20. Com base no "UPR Info's Database of recommendations and VP Comprehensive help guide"(UPR-Info,

2014c), a recomendação dada pelo Estado em Revisão pode ser dividida em cinco categorias: 1. Ação Mínima: como por exemplo, a recomendação de "Compartilhar Experiências"; 2. Ação Continuada: a que pede que 0 Estado "continue a atuar" em uma determinada área; 3. Ação de Consideração: aquelas que pedem que 0 Estado "Considere ratificar" ou tomar uma ação; 4. Ação Geral: como a que pede que 0 Estado "Melhore os direitos das mulheres"; e 5. Ação Específica: como por exemplo, a ação de emendar a legislação atual". (UPR-Info, 2014c, p. 2). Essas categorias são ranqueadas de 1 a 5, de acordo com o grau de envolvimento que o Estado sob revisão apresentou em relação à recomendação. Essa é uma metodologia de apresentação de dados criada por Edward R. McMahon da Universidade de Vermont nos EUA com o apoio da UPR-Info (MCMAHON; ASCHERIO, 2012, p. 236). Neste caso, a categorização das ações é realizada por meio da análise dos verbos textualmente apresentados pelos Estados (UPR-INFO, 2014a).
Tabela 7 - Principais temas das recomendações aos EUA no Primeiro Ciclo

\begin{tabular}{c|c|c|c}
\hline Rank & Temas & $\begin{array}{c}\text { Total } \\
\text { Recomendações }\end{array}$ & $\begin{array}{c}\text { \% do total de } \\
\text { Recomendações }\end{array}$ \\
\hline 1 & $\begin{array}{c}\text { Instrumentos } \\
\text { Internacionais }\end{array}$ & 83 & 29,64 \\
\hline 2 & Direito das Crianças & 35 & 12,5 \\
\hline 3 & Detenções & 35 & 12,5 \\
\hline 4 & Pena de Morte & 32 & 11,43 \\
\hline 5 & Migrantes & 29 & 10,36 \\
\hline
\end{tabular}

Fonte: Elaborado pelos autores com os dados extraídos de UPR-Info, (2017)

O excepcionalismo implica na não ratificação de tratados internacionais de direitos humanos e na não aceitação da jurisdição de tribunais internacionais. Assim, as recomendações que se abrigam na categoria dos instrumentos internacionais requerem que os EUA ratifiquem esses tratados. Conforme vemos na tabela acima, há um grande número de recomendações, acima da média, para os temas de instrumentos internacionais.

Tabela 8 - Principais temas das recomendações aos EUA no Segundo Ciclo

\begin{tabular}{c|c|c|c}
\hline Rank & Temas & $\begin{array}{c}\text { Total de } \\
\text { Recomendações }\end{array}$ & $\begin{array}{c}\text { \% do total de } \\
\text { Recoemndações }\end{array}$ \\
\hline 1 & $\begin{array}{c}\text { Instrumentos } \\
\text { Internacionais }\end{array}$ & 110 & 28.35 \\
\hline 2 & Direito das Crianças & 60 & 15.46 \\
\hline 3 & Direito das Mulheres & 57 & 14.69 \\
\hline 4 & Discriminação Racial & 53 & 13.66 \\
\hline 5 & Pena de Morte & 51 & 13.14 \\
\hline
\end{tabular}

Fonte: Elaborado pelos autores com os dados extraídos de UPR-Info, (2017)

A crítica dos outros Estados à preponderância do modelo excepcionalista dos EUA como forma e justificativa para barrar a ratificação de tratados de direitos humanos se manifesta também no segundo ciclo e perfaz um total de 110 recomendações sobre o tema. Se cruzarmos os dados com as categorias de ações ${ }^{20}$ recomendadas presente nas tabelas abaixo, verificaremos que a maior parte das recomendações de ações específicas feitas aos EUA são recomendações de ratificação desses tratados.

Tabela 9 - Tipos de Ações Requeridas do Estado em Revisão no Primeiro Ciclo.

\begin{tabular}{c|c|c|c}
\hline Rank & Categoria de Ações & $\begin{array}{c}\text { Total de } \\
\text { Recomendações }\end{array}$ & $\begin{array}{c}\text { \% das 280 } \\
\text { Recomendações }\end{array}$ \\
\hline 1 & Ações Específicas (5) & 145 & 51.79 \\
\hline 2 & Ações Gerais (4) & 95 & 33.93 \\
\hline 3 & Ações de Consideração (3) & 31 & 11.07 \\
\hline 4 & Ações Contínuadas (2) & 9 & 3.21 \\
\hline
\end{tabular}

Fonte: Elaborado pelos autores com os dados extraídos de UPR-Info, (2017)

O mesmo é observado no segundo ciclo: 
Tabela 10 - Tipos de Ações Requeridas do Estado em Revisão no Segundo Ciclo

\begin{tabular}{c|c|c|c}
\hline Rank & Categoria de Ações & $\begin{array}{c}\text { Total de } \\
\text { Recomendações }\end{array}$ & $\begin{array}{c}\text { \% das 388 } \\
\text { Recomendações }\end{array}$ \\
\hline 1 & Ações Específicas (5) & 187 & 48.2 \\
\hline 2 & Ações Gerais (4) & 137 & 35.31 \\
\hline 3 & Ações de Consideração (3) & 42 & 10.82 \\
\hline 4 & Ações Continuadas (2) & 22 & 5.67 \\
\hline
\end{tabular}

Fonte: Elaborado pelos autores com os dados extraídos de UPR-Info, (2017)

A leitura das tabelas em conjunto indica que o processo de RPU se constitui em uma oportunidade para os outros Estados integrantes do regime internacional de direitos humanos reagirem à postura excepcionalista dos EUA. Os dados acima mostram que das 145 ações específicas recomendadas para os EUA no primeiro ciclo, 83 delas se referem à ratificação de tratados internacionais de direito humanos. Neste caso, somente $25 \%$ das recomendações feitas aos EUA referem-se a ações específicas que não se relacionam com a ratificação de tratados, enquanto que outros $50 \%$ referem-se a recomendações gerais sem um conteúdo vinculante. O mesmo ocorre no segundo ciclo, uma vez que das 187 recomendações de ações específicas, 110 (ou 59\% das recomendações de ações específicas) são pedidos para que os EUA ratifiquem tratados internacionais.

Assim, a maior parte das recomendações pedem ações de política pública com baixo impacto direto no bem-estar dos cidadãos e cidadãs norte-americanas. Ou seja, são recomendações cujo eventual acatamento pelos EUA não necessariamente gerará impactos verificáveis na vida dos indivíduos, tendo em vista que o fato de um país aderir a um tratado, pela própria ausência de mecanismos robustos de enforcement em tratados, não garante necessariamente a melhoria da vida dos cidadãos e cidadãs daquele país. $\mathrm{Na}$ realidade, esse alto número de recomendações especificamente voltadas à ratificação de tratados internacionais evidencia muito mais a ausência dos EUA dos mecanismos vinculantes que conformam o regime de direitos humanos, tradicionalmente repelidos pelas justificativas fornecidas pela narrativa do excepcionalismo americano. Os números mostram a politização desse tema e permite que outros Estados escrutinem essa narrativa.

Algumas breves reflexões sobre o governo Trump no $\mathrm{CDH}^{21}$

Por fim, há questões sobre a atual relação entre os EUA e o $\mathrm{CDH}$ na administração Trump que merecem alguns comentários exploratórios neste esforço de mapeamento do engajamento do país no órgão. No caso do Conselho de Direitos Humanos, no qual Obama recolocou os EUA e submeteu o país a duas robustas rodadas da RPU, o horizonte contém dois cenários em relação à administração Trump: uma seria a saída do Conselho, o que não seria tão surpreendente não só à luz dos discursos e posturas de campanha, mas tendo em vista o tipo de relação que a última administração republicana manteve com o órgão (votação contrária à criação, saída e boicote orçamentário); a outra, menos drástica, seria uma postura publicamente crítica condicionando o apoio e a permanência dos EUA no órgão a reformas substantivas.
21. Este artigo foi redigido, submetido e aprovado antes da saída dos EUA do $\mathrm{CDH}$, anunciada em 19 de junho de 2018. 
22. This, of course, is the scandalous provision that singles out Israel for automatic criticism. There is no legitimate human rights reason for this agenda item to exist. It is the central flaw that turns the Human Rights Council from an organization that can be a force for universal good, into an organization that is overwhelmed by a political agenda.
Depois da primeira ida da embaixadora dos EUA na ONU, Nikki Haley, em 6 de junho de 2017 à sessão do Conselho em Genebra, a expectativa se aproximou temporariamente do segundo cenário. Segundo o quadro pintado por ela, os EUA pressionarão por reformas no órgão e estarão dispostos a liderar tais esforços. Apesar de reconhecer - de forma mais genérica e abstrata - o papel institucional do Conselho de Direitos Humanos da ONU no avanço das lutas por direitos e na denúncia de violações e violadores, a tônica da posição de Haley foi bastante crítica ao órgão. Segundo ela, quando o Conselho falha em seu papel, o que não é infrequente na visão dos EUA, eleva-se a suspeita de que ele não seja um bom investimento em matéria de tempo, dinheiro e capital político.

Nesse sentido, a administração Trump vê a necessidade de reformas consideráveis. O primeiro ponto, remetendo às críticas de Bush no momento de substituição da Comissão pelo Conselho em 2006, seria uma modificação do processo eleitoral a fim de, na visão estadunidense, impedir que violadores sistemáticos de direitos humanos obtenham cadeiras. Haley chegou a advogar que a eleição deixe de ser secreta e passe a ser aberta. No contexto atual, as candidaturas às cadeiras são negociadas informalmente por cada um dos grupos regionais e, feitas as negociações, o número de candidaturas é exatamente o mesmo do número de cadeiras disponíveis, conformando-se, assim, uma eleição não competitiva, algo criticado pelo atual governo dos EUA. Haley, entretanto, estrategicamente não relembrou a audiência de que os EUA, sob a presidência de Obama, obtiveram uma das três cadeiras disponíveis ao seu grupo regional em um processo eleitoral que contou justamente com apenas outras duas candidaturas, e que a candidatura estadunidense foi a que recebeu menos votos entre as três.

O segundo ponto crítico explicitado pela embaixadora de Trump, comum tanto ao governo Bush quanto ao governo Obama, é a remoção do chamado item 7 da agenda do Conselho. Sob o item 7, o órgão aborda de forma permanente e exclusiva a situação dos direitos humanos nos territórios palestinos ocupados, colocando invariavelmente o governo de Israel sob os holofotes. Todas as outras situações de violações sistemáticas ocorrendo no mundo, quando abordadas, são alocadas sob o item 4 da agenda, destinado a situações que requerem a atenção do Conselho. Nas palavras da embaixadora:

Isto, é claro, é a provisão escandalosa que separa Israel das críticas automáticas. Não há razão legítima de direitos humanos para que esse item da agenda exista. É a falha central que transforma o Conselho de Direitos Humanos de uma organização que pode ser uma força para o bem universal, em uma organização que está sobrecarregada por uma agenda política ${ }^{22}$. (LIMON, 2017, p. 6, tradução nossa)

A questão é que a eventual remoção do item 7 exigiria a aprovação de uma resolução emendando o chamado Institution-building Package (IBP), uma série de acordos sobre o Conselho firmados em seu primeiro ano de funcionamento. Aprovada essa resolução em Genebra, ela também teria que receber a anuência positiva da Assembleia Geral. Do ponto de vista procedimental, isso é possível, porém, rediscutir o IBP abrirá a chance para que outras emendas sejam inseridas, as quais poderão, por exemplo, revogar também o item 4 da agenda, citado acima, ou ainda ex- 
tinguir os mandatos de relatores especiais para países específicos. Estarão os EUA e seus aliados dispostos a correr esse risco?

A complexidade para remover o item 7 , tal como quer a gestão Trump, revela o alto preço pago pelos EUA em razão do governo Bush ter retirado o país do Conselho. Estando ausente do órgão durante as negociações do IBP, os EUA não proporcionaram a Luis Alfonso de Alba, à época presidente do Conselho, respaldo para bloquear a inclusão do referido item 7 . Esse argumento se reforça à medida que se observa uma redução de resoluções sob esse item a partir da entrada dos EUA em 2009 com a administração Obama. Portanto, essa pauta revela os custos de médio prazo que os EUA podem vir a sofrer mais uma vez com um eventual novo desengajamento do órgão.

Entretanto, diante das posições até aqui apresentadas pela administração Trump, tais críticas não parecem ter sido ainda suficientes para que os EUA optem por sair novamente do Conselho (ainda que uma eventual saída tenha ficado menos implausível após a saída recente do país da UNESCO). O tom atual, nas palavras de Haley, é o seguinte: "America does not seek to leave the Human Rights Council. We seek to reestablish the Council's legitimacy." (LIMON, 2017, p. 4)

Considerações finais

Com base nos dados apresentados referentes à participação dos Estados Unidos no mecanismo da Revisão Periódica Universal do Conselho de Direitos Humanos, pensados a partir dos modelos de política externa para os direitos humanos deste país, pudemos fazer um mapeamento crítico do engajamento da potência nesse órgão. Mostramos a forma como os modelos de excepcionalismo e pragmatismo casuístico tomaram forma durante o governo Obama e quais foram os custos que a administração democrata teve que pagar pelo desengajamento do seu antecessor.

Neste inédito esforço de sistematização, observamos que os dados nos mostram uma interessante agenda de pesquisa para os próximos anos. Entre esses temas, destacamos a posição francesa - um aliado ocidental - apresentando o maior número de recomendações aos EUA no segundo ciclo a despeito da estratégia apontada pela literatura segundo a qual os aliados se blindam contra críticas no órgão; um aprofundamento maior da questão do Noted, isto é, o que essa forma de rejeição de fato significa e quais foram as rejeições que as organizações sociedade civil conseguiram eventualmente reverter; além de um enfoque maior no engajamento dos EUA enquanto revisor no mecanismo.

Um promissor próximo passo para essa agenda de pesquisa é o monitoramento da temática no governo Trump. Esse governo, eleito a partir de uma plataforma bastante avessa ao multilateralismo e ao sistema de direitos humanos da ONU, já insinuou uma nova saída do Conselho caso não consiga reformá-lo estruturalmente (advogando pontos muito parecidos com aqueles pontos defendidos pelo governo Bush e não atendidos nas negociações de 2005 e 2006). O cenário, portanto, reafirma a tendência histórica de relações tensas e ambivalentes entre os EUA e as 
instâncias internacionais de direitos humanos.

Caberá observar qual será a tendência da administração Trump. Desde a campanha presidencial de 2016, o atual presidente vem tecendo inúmeras críticas à ONU e às suas instâncias de direitos humanos. A partir de sua vitória e de sua posse, criou-se uma expectativa relativamente generalizada na comunidade internacional de que os EUA, a partir de agora, colocariam em prática um desengajamento das instituições multilaterais e de seus fóruns e acordos. A saída recente dos EUA do Acordo de Paris sobre o clima e da UNESCO talvez tenham sido as mais palpáveis concretizações dessa expectativa. Ainda assim, a postura do governo Bush mostrou que, a despeito de todo o peso do país, o Conselho foi criado, teve suas principais regras acordadas e foi posto em pleno funcionamento sem a presença dos EUA, os quais passaram a fazer parte de um órgão sobre o qual detêm pouco controle, mas não o construíram. Estariam os EUA novamente dispostos a recorrer aos mesmos expedientes que o Governo Bush?

Referências

ABEBE, A. M. Of Shaming and Bargaining: African States and the Universal Periodic Review of the United Nations Human Rights Council. Human Rights Law Review, v. 9, n. 1, p. 1-35, 2 fev. 2009.

ALSTON, P. Reconceiving the UN human rights regime: challenges confronting the new UN Human Rights Council. Melb. J. Int'l L., v. 7, p. 185, 2006.

ANNAN, K. In larger freedom: towards security, development and human security for all, United Nations, UN Doc A/59/2005, 2005.

ANNAN, K. Major Proposals to Reform UN Human Rights Machinery: (Discurso no Conselho de Direitos Humanos, em 7 de abril de 2005). Disponível em: <http://www.un.org/press/ en/2005/sgsm9808.doc.htm>. Acesso em: 10 jul. 2017.

BELLI, B. Perspectivas do novo Conselho de Direitos Humanos da ONU. Política Externa, São Paulo, v. 17, n. 3, p. 49-64, 2008/2009.

BERGQUIST,Amy. Pledges \& Punts at the UN: The U.S. Government Responds to UPR Recommendations, The Advocstes Post, 2015. Disponível em : <https://theadvocatespost. org/2015/09/24/pledges-punts-at-the-un-the-u-s-government-responds-to-upr-recommendations/> Acesso em: 30 jun.2017

BLANCHFIELD, L. The United Nations Human Rights Council. 8 ago. 2006. Congressional Research Service. Disponível em: $<$ http://www.fas.org/sgp/crs/row/>. Acesso em: 20 ago. 2014.

BLANCHFIELD, L. The United Nations Human Rights Council. 31 jul 2008. Congressional Research Service. Disponível em: <http://www.fas.org/sgp/crs/row/>. Acesso em: 30 set. 2014.

BLANCHFIELD, L. The United Nations Human Rights Council. 1 jun 2009. Congressional Research Service. Disponível em: <http://fpc.state.gov/documents/organization/127027.pdf >. Acesso em: 03 out. 2014

COCHRANE, L.; MCNEILLY, K. The United Kingdom, the United Nations Human Rights Council and the first cycle of the Universal Periodic Review. The International Journal of Human Rights, v. 17, n. 1, p. 152-177, 1 jan. 2013.

COX, E. State interests and the creation and functioning of the United Nations Human Rights Council. J. Int'l L \& Int'l Rel., v. 6, p. 87, 2010.

DURAN, C. 2006. Luzes e sombras do novo Conselho de Direitos Humanos das Nações Unidas. SUR: Revista Internacional de Direitos Humanos, ano 3, n. 5, p. 7-18.

FREEDMAN, R. New Mechanisms of the UN Human Rights Council. Netherlands Quarterly of Human Rights, v. 29, n. 3, p. 289-323, 2011.

FREEDMAN. The United States and the UN Human Rights Council: An Early Assessment. 2009. FORSYTHE, David. Turbulent transition: from the UN Human Rights Commission to the Council. In KAUFMAN, Scott; WARTERS, Alissa (eds.). The United Nations: past, present, and future. New York: Nova Science Publishers, 2009.

FORSYTHE. US foreign policy and human rights: situating Obama. Human Rights Quarterly, 
v. 33, n. 3, 2011, p. 767-789.

KHALILZAD, Z. Remarks on Peacebuilding, Burma, Somalia, Human Rights Council elections, detainees, and Lebanon, at the Security Council stakeout. Disponível em: <http:// archive.usun.state.gov/press_releases/20080520_125.html>. Acesso em 18 jul. 2015.

KNIGHT, A. 60 años de la ONU: de un impulso transformista a la transformación. In: ROSAS, M. C. (Ed.). 60 años de ONU: que debe cambiar. México: UNAM: ANU, 2005

LIMON, Marc. President Trump and the Human Rights Council: what did we learn from Nikki Haley's visit? Disponível em: $<$ http://www.universal-rights.org/blog/president-trump-human-rights-council-learn-nikki-haleys-visit/ >. Acesso em 03 jul 2017.

LYONS, G. M.; BALDWIN, D. A.; MCNEMAR, D. W. The "Politicization" Issue in the UN Specialized Agencies. Proceedings of the Academy of Political Science, v. 32, n. 4, p. 81, 1977.

MCCORMACK, S. Press Release: US State Department. Washington, DC. 6 mar, 2007. Disponível em:< http://www.scoop.co.nz/stories/WO0703/S00131.htm>. Acesso em: 03 out. 2016.

MCMAHON, E.; ASCHERIO, M. A Step Ahead in Promoting Human Rights? The Universal Periodic Review of the UN Human Rights Council. Global Governance: A Review of Multilateralism and International Organizations, v. 18, n. 2, p. 231-248, 2012.

MULLER, L. The first 365 days of the United Nations Human Rights Council. Geneva, Swiss Embassy, 2006.

OBAMA, B. Barack Obama’s Inaugural Address. Washington, DC. 21 jan. 2009. Disponível em<http://www.whitehouse.gov/blog/inaugural-address/>. Acesso em: 03 out. 2016.

SHORT, K. 2008. Da Comissão ao Conselho: a Organização das Nações Unidas conseguiu ou não criar um organismo de Direitos humanos confiável? SUR: Revista Internacional de Direitos Humanos, São Paulo, ano 5, n. 9, p. 173-199.

SIKKINK, K. Latin America's Protagonist Role in Human Rights. SUR: Revista Internacional de Direitos Humanos. December 2015, p. 207-219.

TICHENOR, Warren. U.S. Statement by Ambassador Warren W. Tichenor. Human Rights Council, $1^{\text {st }}$ session, June $26,2006 \mathrm{~b}$.

UNITED NATIONS. GENERAL ASSEMBLY. Um mundo mais seguro: nossa responsabilidade compartilhada. A/59/565, 2004.

UNITED NATIONS. GENERAL ASSEMBLY. GENERAL ASSEMBLY. Agenda of the sixtieth session of the General Assembly. A/60/251, 2006a.

UNITED NATIONS. GENERAL ASSEMBLY GENERAL ASSEMBLY. HUMAN RIGHTS COUNCIL. Report of the Human Rights Council on its second session. A/HRC/2/9, $2006 \mathrm{~b}$.

UNITED STATES. US Congress. H.R. 2764. Consolidated Appropriations Act, 2007a.

UNITED STATES. US Congress. H.R. 557, $110^{\text {th }}$ Congress, $1^{\text {st }}$ Session, 2007c.

UNITED STATES. US Mission to UN. Ambassador Susan E. Rice. 2009 Disponível em: <http://usun.state.gov/leadership/c31461.htm>. Acesso em 02 out. 2014.

UNITED STATES. US Mission to UN. Eileen Chamberlain Donahoe, U.S. Ambassador to the Human Rights Council, 2010. Disponível em: <http://geneva.usmission.gov/2010/03/13/ donahoe-bi/>. Acesso em: 02 out. 2014.

UPR-INFO. UPR Info’s Database: Action category ,2014a. Disponível em: $<$ https://www.upr-info.org/database/files/Database_Action_Category.pdf> Acesso em: 15 mai. 2017.

UPR-INFO. UPR Info's Database: Issue categorisation, 2016. Disponível em: < https://www. upr-info.org/database/files/Database_Action_Category.pdf>, acesso em: 20 mai. 2017.

UPR-INFO. UPR Info's Database: Methodology Responses to recommendations, 2014b. Disponível em: <https://www.uprinfo.org/database/files/Database_Methodology_Responses_to_ recommendations.pdf $>$, acesso em: 10 mai. 2017.

UPR-INFO. UPR Info's Database of recommendations and VP Comprehensive help guide, 2014c, disponível em: <https://www.upr-info.org/database/files/Database_Help_Guide.pdf>, acesso em 15 mai. 2017.

U.S. ENVOY REFUSES EXIT COMMENT. BBC Politics. 7 dez. 2006. Disponível em: < http:// news.bbc.co.uk/2/hi/americas/6216726.stm >. Acesso em: 10 ago. 2011. 